result of fast air travel. Indeed, a number of cases have been treated in a London hospital. Monath (WHO Chronicle, 28, 212; 1974) wrote that a programme of surveillance must be instituted both in West Africa and in the developed countries. To this one should add the provision of hospital isolation and laboratory facilitios in selected centres.

\section{Sicily as part of Africa}

from Peter J. Smith

ACCORDING to Barberi et al. (J. geophys. Res., 78, 5221; 1973), the southern Tyrrhenian Sea contains an island arc structure which includes a sediment filled trench along the Ionian coast of Calabria, a metamorphic belt stretching along Calabria into Sicily, a calcalkaline volcanic arc in an advanced state of evolution (Eolian Islands) and a back-arc marginal basin (Tyrrhenian Abyssal Plain). In short, the Tyrrhenian Sea area is readily interpreted in the light of the destructive boundary between the African and European plates. But where precisely does the plate boundary lie in this region? McKenzie (Geophys. J., 30, 109; 1972) and several other workers have proposed that the boundary line actually crosses northern Sicily, in which case most of Sicily will be a part of the African plate. New evidence in favour of this view has now come from two quite different sources.

Evidence adduced by Barberi et al. (Earth planet. Sci. Lett., 22, 123; 1974) comes from the distribution, age, nature and palaeomagnetism of volcanic rocks in the east of the island, although the volcanics are only one of five principal provinces in Sicily. In the extreme south-east lies the RagusaIblei carbonate platform which is not affected by Alpine folding and seems to be an extension of the Sahara platform. In other words, the southernmost part of Sicily is apparently linked geologically with Africa-a view supported by the existence of $20 \mathrm{~km}$-thick continental type crust to the south of the island. Central and western Sicily comprise a Mio-Pliocene resedimentation basin; and in the north there is a series of flysch nappes ranging in age from Cretaceous to Miocene. But the extreme north-east of the island is a crystalline massif forming the continuation of the Calabrian metamorphic belt. In other words, the northernmost part of Sicily is apparently linked geologically with Europe. The view that the Euro-African plate boundary crosses Sicily is thus supported in general terms by the geology.

For a more quantitative picture of
Sicily's behaviour, however, it is necessary to look at the eastern part, which has been a site of dominantly basaltic volcanism since the middle Triassic (although only Cretaceous and younger rocks are exposed). The most recent episodes of (subaerial) volcanism are represented by Mt Etna and Mt Iblei; but all volcanic activity before this was submarine, giving rise to pillow lavas and hyaloclastics emitted through fissures in a carbonate platform. The oldest rocks examined palaeomagnetically by Barberi and his colleagues were Upper Cretaceous dykes (with potassium-argon ages in the range 71-84 million years) cutting hyaloclastics of three different Cretaceous outcrops. From Cretaceous to Upper Miocene no basaltic volcanism occurred in the region, although important activity has occurred since, principally in the vicinity of Iblei and Etna. The second set of rocks studied was therefore of Iblei volcanics within the age range 1.7-5.4 million years.

The palaeomagnetic results are simply stated. The Upper Cretaceous pole is consistent with that for Africa obtained by Shazly and Krs (Geol. $R d s c h ., 62,212$; 1973) but significantly different from the mean Cretaceous pole for Europe. The Plio-Pleistocene pole for Sicily is consistent with the mean Upper Tertiary-Quaternary poles for the Central European-Russian platform and for the French Massif Central lavas and with the Quaternary poles for Africa and Spain (Gerona volcanics). It thus seems that there has been no significant motion of eastern Sicily with respect to Africa since the Cretaceous. On the other hand, Sicily has moved with respect to Europe since the Cretaceous, but not since the end of the Miocene. The implication, therefore, is that (with the probable exception of the extreme northeast of the island) Sicily has been part of the African plate since the Cretaceousand thus in all likelihood since at least the Triassic.

Barberi and his colleagues then visualise Sicily's fitting into the evolutionary pattern of the region in the following way. From the Upper Triassic to the Upper Cretaceous the African plate moved south-easterly with a sinistral shear movement with respect to Europe, resulting in a separation of the African and European plates and the formation of oceanic crust. The northern edge of the African plate (and thus Sicily) then underwent distensiona process consistent with the alkalic products of volcanism observed in Sicily for the relevant period. From the Upper Cretaceous to the present the motion of Africa with respect to Europe has been mainly compressional with minor dextral movement-a change also reffected in Sicilian volcan- ism. Basaltic distensive volcanism was absent from eastern Sicily from the Upper Cretaceous to the Upper Miocene. The occurrence of Upper Oligocene-Lower Miocene andesitic volcanism suggests, however, that the compression between Africa and Europe was accompanied by subduction of the oceanic crust previously formed between Sicily and Europe, a process which gave rise to island arc type volcanism towards the end of the Oligocene. Crustal consumption lasted until the Lower Miocene, when the continental collision occurred; and since the late Miocene Sicily has been joined to Europe, as the Iblei palaeomagnetic data indicate.

An obvious problem with this scheme is the post Miocene and current basaltic distensive volcanism in eastern Sicily, which is difficult to explain in terms of the general tectonic framework of compression. The explanation put forward by Barberi et al. is that continental collision has occurred at different points along the Sicilian-Calabrian segment of the plate boundary at different times, possibly because of the irregular shapes of the encroaching continents. For example, the subduction of oceanic crust beneath the Calabrian arc is still active (hence the Eolian island arc), although the continental nature of the crust on both sides of the boundary suggests that crustal consumption is now nearly complete. In any event, since the Lower Miocene eastern Sicily has been the border zone between colliding continental blocks and the oceanic lithosphere subducting beneath the Calabrian arc, and has thus probably been affected by local distension, notwithstanding the general overall compression.

The second piece of evidence supporting the view of Sicily as part of Africa comes from laser geodimeter measurements between the island and Calabria on the Italian mainland. Caputo et al. (Geophys. J., 38, 1; 1974) report six sets of such measurements made between September 1970 and September 1973. Needless to say, even with lasers it is a difficult task to determine the very small distance changes likely to be involved over such a short period; and the variations in the lengths of the sides of the Sicily-Calabria geometric net are indeed found to be generally smaller than the measurement errors and data corrections. Nevertheless, Caputo and his colleagues tentatively conclude that a statistically significant displacement between Sicily and Calabria took place between September 1970 and June 1971. During this period (but not subsequently) Sicily was displaced roughly northward with respect to the mainland, implying that it participates in the movements of Africa rather than Europe. 